\title{
JIE
}

JOURNAL OF ISLAMIC EDUCATION

Vol. 7 No. I Mei 2022

P-ISSN 2503-5363; E-ISSN 2528-0465

http://www.ejournal.stitmuhbangil.ac.id/index.php/jie

\section{Tantangan Pendidikan Akhlak pada Sistem Pembelajaran Daring}

\author{
*Iwantoro ${ }^{1}$, Wachyudi Achmad ${ }^{2}$ \\ ${ }^{1,2}$ (Sekolah Tinggi Ilmu Tarbiyah (STIT) Muhammadiyah Bangil, Jl. Alun-Alun Tim. \\ No.2, Pasuruan, Indonesia) \\ *iwan.stitmuhbangil@gmail.com
}

\begin{tabular}{l}
\hline Informasi Artikel \\
\hline Received: \\
1 December 2021 \\
Accepted: \\
10 March 2022 \\
Published: \\
4 May 2022 \\
Keywords: \\
Moral Education, Online \\
Learning System.
\end{tabular}

\begin{abstract}
The existence of the Covid-19 pandemic, which is the main reason why the activities of the world community are diverted, from offline activities to online, cannot be separated from the Indonesian people who also feel the impact, especially the Indonesian education world. Community representatives in the education aspect are required to issue policies related to learning system innovations that can be used to cope with the impact of the Covid-19 pandemic. This study purposed to describe the process of inculcating moral education value to the student's learning during the COVID-19's pandemic (E-learning). Methods for extracting data by using literature study either through the theories from references sourced books or from research results from educational journals. The results of this study suggest that the cultivation of students' moral education is related to the active role of parents. Teachers need to build and carry out a comprehensive approach with the parents. The active role of parents can be in the form of giving a good examples and habits during the pandemic.
\end{abstract}

Adanya pandemi Covid-19 yang menjadi alasan utama beralihnya aktivitas masyarakat dunia, dari aktivitas offline menjadi online, tidak lepas dari masyarakat Indonesia yang turut merasakan dampaknya, khususnya dunia pendidikan Indonesia. Perwakilan masyarakat di bidang 


\begin{abstract}
pendidikan dituntut untuk mengeluarkan
kebijakan terkait inovasi sistem pembelajaran yang dapat digunakan untuk mengatasi dampak pandemi Covid-19. Penelitian ini bertujuan untuk mendeskripsikan proses penanaman nilai pendidikan moral pada pembelajaran siswa selama masa pandemi COVID-19 (E-learning). Metode penggalian data dengan menggunakan studi kepustakaan baik melalui teori-teori yang bersumber dari buku-buku referensi maupun dari hasil penelitian dari jurnal-jurnal pendidikan. Hasil penelitian ini menyarankan bahwa penanaman pendidikan moral siswa berkaitan dengan peran aktif orang tua. Guru perlu membangun dan melakukan pendekatan yang komprehensif dengan orang tua. Peran aktif orang tua dapat berupa memberikan contoh dan kebiasaan yang baik di masa pandemi.
\end{abstract}

\title{
I. PENDAhUluan
}

Pandemi Corona Virus 2019 atau yang biasa disingkat dengan Covid-19 telah memberikan pengaruh yang besar terhadap pelaksanaan pendidikan di negeri ini bahkan di negara lain. Sebelum pandemi menjangkit dunia, khusus di Indonesia pelaksanaan pembelajaran dilakukan secara regular atau luar jarring (luring), tetapi sejak pandemi Covid-19 menjangkiti Indonesia pembelajaran dilaksanakan secara online (daring) dengan segala keterbatasannya. Karena kondisi yang menuntut dilakukannya pembelajaran secara online tersebut (Maryano \& Sholeh, 2021).

Banyak tantangan yang dihadapi dalam menjalankan pembelajaran yang dapat dikatakan sebagai revolusi dalam dunia pembelajaran di Indonesia ini. Tantangan tersebut antara lain meliputi: kesiapan/kompetensi tenaga pendidik (guru), keterbatasan media pembelajaran yang digunakan (laptop, gadget, dan sejenisnya), keterbatasan dana dalam pembelian pulsa/paket data, dan ketersedian infrastruktur (jaringan internet) karena kondisi geografis daerah.

Kondisi tersebut di atas merupakan tantangan-tantangan yang relatif sulit untuk pecahkan dalam waktu singkat. Oleh karena itu perlu penanganan dan kebijakan khusus untuk meminimalisir permasalahan-permasalahan tersebut. Di 
samping itu perlu kerja keras dan serius dari berbagai pihak mulai dari pemerintah, masyarakat, sampai kepada pelaksana program yaitu satuan pendidikan dalam hal ini adalah guru/pendidik.

Setidaknya ada beberapa hal yang dianggap sebagai tantangan dalam pendidikan Islam. Pertama, pengembangan potensi manusia. Mengembangkan potensi manusia dalam perspektif pendidikan Islam merupakan tantangan yang holistik, berkesinambungan, dan tiada akhir. Kedua, membahas kegagalan para pemikir Barat dalam mengonstruksi paham tentang hakikat asal usul manusia yang tidak berpedoman pada wahyu. Ketiga, kita membahas tantangan yang ditimbulkan oleh budaya fatalistik Islam sendiri. Keempat, mengkaji munculnya ancaman di abad XXI yang dipengaruhi oleh faktor-faktor perubahan sosial (Suparnis, 2016).

Dalam kaitan dengan pendidikan dalam rangka penanaman akhlak tentu harus lebih serius lagi. Karena penanaman karakter atau akhlak memerlukan strategi khusus mengingat yang digarap adalah hal yang fundamental. Sehingga pembelajaran online (dalam jaringan) memberikan nuansa yang jelas berbeda dengan pendekatan belajar "manual" (Aqil, 2018).

\section{METODE PENELITIAN}

Penelitian ini menggunakan pendekatan "library research" dengan melakukan kajian-kajian kepustakaan dalam rangka memberikan gambaran utuh terkait dengan cara mengumpulkan berbagai sumber atau referensi yang membahas tentang penanaman pendidikan akhlak melalui pembelajaran dalam jaringan berserta tantangan yang dihadapinya (Ikhwan, 2021).

\section{TEMUAN DAN PEMBAHASAN}

\section{Tantangan Penanaman Pendidikan Akhlak}

Dunia sedang berperang melawan Covid 19. Lembaga pendidikan perlu membuat prediksi cepat. Mirip dengan flu pandemi, praktik yang paling umum digunakan di sekolah adalah membatalkan atau menunda kegiatan belajar di sekolah, membatalkan kelas atau kegiatan dengan tingkat campur aduk/kontak tinggi yang terjadi selama jam pelajaran, dan penggunaan sarana transportasi 
untuk mengurangi jumlah interaksi fisik pada siswa (Uscher-Pines et al., 2018). Institusi pendidikan di seluruh dunia telah ditutup sementara oleh pemerintah, yang mempengaruhi sistem akademik. Mereka perlu menemukan opsi baru untuk belajar, kelas virtual/pembelajaran online adalah cara yang paling mungkin (Wahyono, Husamah, \& Budi, 2020).

Pada awal pandemi Covid-19 sempat pemerintah meliburkan kegiatan pembelajaran dari jenjang paling bawah (Sekolah Dasar) sampai jenjang paling tinggi yakni perguruan tinggi. Berbagai kebijakan dikeluarkan pemerintah dalam rangka menekan angka keterjangkitan/penularan wabah Covid-19, termasuk di sekolah-sekolah yang pada akhirnya proses atau kegiatan pembelajaran dilakukan secara online atau dalam jaringan (Nasir \& Prastowo, 2021).

Belajar dengan teknologi baru telah berlangsung selama beberapa dekade. Namun, dapat dikatakan bahwa efek transformasional yang diharapkan tidak tercapai secara optimal (Trucano, 2014). Dalam hal ini, beralih ke pembelajaran online, tentu saja, bukan solusi yang tepat secara utuh. Di Amerika Serikat saja, banyak profesor tidak mengajar secara online, sementara dalam pelaksanaannya seringkali kekurangan dukungan teknis. Perubahan tersebut telah menuai kritik apakah perlu tanpa keterlibatan lembaga yang memadai. Yang lain bertanya-tanya apakah model online murni menempatkan siswa yang mungkin tidak memiliki akses ke digital atau Internet merupakan sebuah hukuman atau kerugian.

\section{Kompetensi Guru/Tenaga Pendidik}

Guru atau pendidik merupakan unsur utama dalam pelaksanakan pembelajaran daring ini, oleh karena itu perlu kompetensi yang cukup dan perlu disiapkan secara matang guna meminimalisir kekurangan yang ada. Masih banyak guru di negeri ini masih "gagap teknologi" khususnya yang berada di daerahdaerah terpencil bahkan tidak menutup kemungkinan guru-guru yang ada di perkotaan. Mengutip data Ikatan Guru Indonesia (IGI), Wakil Ketua MPR Lestari Moerdijat mengatakan, $60 \%$ guru memiliki pengetahuan teknologi informasi di bidang pendidikan yang sangat minim akibat penerapan pembelajaran jarak jauh dalam tiga bulan terakhir (Satariyah, 2020). 
Kompetensi guru dalam hal ini adalah guru Pendidikan Agama Islam (PAI) khususnya bidang teknologi informasi dan komunikasi ini menjadi hal yang perlu diperhatikan oleh guru. Kompetensi ini adalah kompetensi profesional yang harus dimiliki guru, seperti dijelaskan dalam Undang-Undang RI No. 14 tahun 2005, yang dimaksud kompetensi profesional adalah kemampuan menguasai pelajaran secara luas dan mendalam. Sedangkan menurut permendiknas No. 16 tahun 2007, kompetensi profesional terdiri dari: (a) menguasai materi, struktur, konsep dan pola pikir keilmuan yang mendukung mata pelajaran yang diampu, (b) menguasai standar kompetensi dan kompetensi dasar mata pelajaran yang diampu, (c) mengembangkan materi pelajaran yang diampu secara kreatif, (d) mengembangkan keprofesionalan secara berkelanjutan dengan melakukan tindakan reflektif, dan (e) memanfaatkan teknologi informasi dan komunikasi untuk mengembangkan diri.

Pada item terakhir dinyatakan bahwa guru harus dapat memanfaatkan teknologi informasi dan komunikasi untuk mengembangkan diri. Dalam proses pembelajaran guru berkewajiban tidak ketinggalan dengan teknologi informasi (Iwantoro, 2018). Dalam pembelajaran daring kemampuan dalam mengoperasikan media pembelajaran mutlak harus dimiliki oleh guru. Banyak platform kelas daring yang dapat digunakan baik yang berbayar maupun tidak berbayar. Bagi guru yang biasa "bergelut" dengan IT, tidaklah sulit mengoperasikan kelas daring tersebut, tetapi bagi guru-guru yang selama ini membelajarkan peserta didik dengan pendekatan tradisional tentu memnjadi masalah yang serius.

Dalam sebuah hasil penelitian melalui wawancara dan survey yang dilakukan oleh Myori, dan kawan-kawan di SMKN 1 Koto XI menunjukkan bahwa sekolah tersebut telah dilengkapi dengan laboratorium komputer, jaringan internet, dan LCD di setiap ruang kelas sebagai fasilitas pembelajaran. Akan tetapi, fasilitas tersebut belum digunakan secara maksimal oleh guru dikarenakan tidak memiliki kompetensi untuk melakukan kegiatan belajar mengajar berbasis teknologi informasi (Surahman, Santaria, \& Setiawan, 2020). 
Penelitian yang dilakukan oleh Syukur pada guru SD, SMP, SMA, dan SMK di Kabupaten Nganjuk menunjukkan bahwa terdapat $52,75 \%$ guru jarang menggunakan laptop dalam kegiatan belajar mengajar. Guru yang dilaporkan jarang menggunakan laptop dan internet berusia di atas 45 tahun. Penggunaan laptop dan internet yang sering dilakukan adalah untuk guru berusia 35-45 tahun (Surahman et al., 2020). Hasil penelitian ini menunjukkan bahwa usia guru juga mempengaruhi kemampuan menggunakan teknologi informasi dalam proses pembelajaran.

Dalam pembelajaran daring/online guru tidak boleh hanya sekedar memberikan tugas kepada peserta didiknya, agar tidak menganggur begitu saja tetapi pembelajaran tersebut harus benar-benar bermakna dan menumbuhkan kreativitas peserta didik. Jika prinsip guru hanya memberikan tugas saja maka akan terjadi kejenuhan belajar pada diri peserta didik, karena mereka tidak mendapatkan pengalaman belajar yang menyenangkan dan mengesankan. Dapat dibayangkan kalau itu terjadi, bagaimana kualitas peserta didik pada masa pandemi ini, maka akan terjadi penurunan prestasi belajar pada diri peserta didik.

\section{Sarpras Pendukung Pembelajaran dan Ketersediaan Infrastruktur}

Keberhasilan kegiatan belajar mengajar tidak lepas dari ketersediaan sarana dan prasarana yang ada, sebagai pendukung utama. Dalam konteks pembelajaran daring sarana dan prasarana yang dibutuhkan tergolong mahal (untuk sebagian besar masyarakat). Ketersediaan sinyal internet, gadget (handphone, tablet dan sejenisnya), komputer/laptop mutlak diperlukan dalam pembelajaran online.

Kemampuan sekolah dalam menyediakan sarana tersebut tentu berbeda antara sekolah yang satu dengan sekolah lainnya, termasuk kemampuan wali peserta didik. Kondisi geografis daerah/wilayah juga sangat menentukan kelancaran proses pembelajaran online ini. Sekolah perlu menyediakan anggaran tambahan untuk pemenuhan pembelian paket data untuk guru sekaligus menyediakan media belajarnya bagi guru yang tidak memilikinya, seperti smartphone atau media sejenis yang representatif. Meskipun belakangan pemerintah sudah mulai membantu dengan memberikan paket data kepada guru maupun peserta didik. Tetapi kenyataan yang ada masih banyak orang tua/wali 
peserta didik yang tidak memiliki smartphone, jikapun ada kadangkala dibawa bekerja. Kendala media ini sangat substansial yang sulit untuk dicari solusinya karena terkait dengan keadaaan perekonomian keluarga/masyarakat.

Infrastruktur dari internet terdapat dua jenis yang disediakan oleh penyedia jaringan dan layanan, yaitu: melalui kabel (fiber optic/serat optic) dan media satelit yang kemudian disalurkan melalui tower/pemancar (nirkabel). Perbandingan kecepatan akses internet di Indonesia dengan negara lain berdasarkan fakta dan penelitian yang ada, Indonesia menempati peringkat terbawah di negara-negara kawasan ASEAN, hal ini terjadi karena sebab antara lain: (1) kondisi geografis yang sangat luas dan medan yang beraneka ragam, (2) tingginya angka pengguna internet, (3) perang promosi operator penyedia koneksi internet, dan (4) regulasi pemerintah yang kurang efisien (Lestari, 2015).

Perlu digaris bawahi bahwa kondisi geografis daerah merupakan salah satu hal yang sangat berpengaruh terhadap cepat atau lambatnya akses internet termasuk ketersediaan sinyal internet. Bagi sebagaian wilayah sinyal internet dapat tertangkap bagus, tetapi di sebagian wilayah yang lain sinyal internet sulit bahkan tidak bisa dijangkau oleh smartphone. Daerah atau wilayah pengunungan, pantai dan sebagian pelosok desa adalah area yang biasanya sulit untuk ditembus oleh sinyal-sinyal internet. Tentu keadaan ini sangat menyulitkan peserta didik dalam mengikuti kegiatan belajar online/daring.

\section{Strategi Penanaman Pendidikan Akhlak}

Dalam masa pandemi Covid-19 ini orang tua memiliki peran yang lebih vital dibandingkan guru di sekolah. Hampir setiap hari proses belajar anak dilaksanakan di rumah dengan menggunakan media elektronik (smartphone), hampir guru tidak bisa mengontrol anak-anak didiknya. Oleh karena itu strategi yang digunakan guru untuk menanamkan nilai-nilai moral atau pendidikan akhlak tidak bisa lepas dari peran serta orang tua di rumah (Ikhwan, Anwar, \& Mahmudah, 2021).

Guru perlu membangun komunikasi yang baik dengan orang tua, melalui interaksi yang terprogram dan terukur diharapkan dapat menjadi jembatan proses penanaman akhlak tersebut kepada peserta didik. Paguyuban orang tua perlu dimaksimalkan sebagai wadah komunikasi bukan hanya sebagai wadah untuk 
menarik iuran. Melalui wadah inilah guru dapat memberikan banyak pesan, masukan, dan hal-hal yang diperlukan dalam mendampingi anak didik di rumah.

Orang tualah yang dapat membentuk kepribadian dan persona anak. Orang tua tidak hanya bertanggung jawab untuk membangun persahabatan/kekerabatan dan mewariskan keturunan. Jailani menemukan bahwa peran utama orang tua adalah membangun pondasi akhlak, menciptakan suasana bagi proses pendidikan keluarga, dan menciptakan generasi cerdas yang berkepribadian mulia yang menjadi landasan kokoh bagi kehidupan (Budiman \& Jailani, 2014). Tanggung jawab ini sepenuhnya berada pada orang tua, yang utamanya bertanggung jawab dalam membesarkan keluarga (Yulianingsih, Suhanadji, Nugroho, \& Mustakim, 2021). Mengevaluasi peran orang tua sebagai pembelajar di rumah untuk memenuhi kebutuhan pemahaman spiritual, pengawasan dan motivasi, serta membantu anak mengatasi kesulitan dan merespon dengan baik semua proses pembelajaran. Perlakuan orang tua terhadap anak dapat membentuk dan mempengaruhi kepribadian anak (Rajab, 2009). Sebagaimana Anisah, mengemukakan, perlakuan orang tua terhadap anak akan berpengaruh terhadap perilaku dan kepribadian anak (Anisah, 2017);(Nasution, I dan Suharian, 2020).

\section{Teladan di Masa Pandemi}

Masa pandemi dengan pendidikan dalam jaringan atau online ini benar-benar menempatkan orang tua sebagai center atau pusat pendidikan. Dalam kaitan pendidikan akhlak guru harus bekerjasama dengan orang tua di rumah. Di sini guru benar-benar dituntut untuk dapat bekejasama dan melakukan hubungan timbal balik dalam rangka menanamkan karakter/akhlak kepada peserta didik. Orang tua harus dapat memberikan teladan yang baik kepada anak-anaknya, karena selama 24 jam mereka ada di lingkungan keluarga (Anwar, 2021).

Dalam hal ini penguatan yang diberikan orang tua adalah contoh terbaik dalam pandangan anak, karena segala tindak tanduknya, sopan santunnya, cara berpakaiannya dan tutur kata orang tua akan selalu diperhatikan dan akan ditiru oleh anak. Oleh karena itu orang tua diharapkan mampu memberikan contoh yang baik dengan cara yang benar, kadangkala dalam memberikan contoh teladan yang baik, orang tua kadang menyepelekan atau kurang memperhatikan proses 
65 JIE (Journal of Islamic Education)

e-ISSN: 2528-0465 (online) | Volume 7, Issue 1 | Mei 2022

p-ISSN: 2503-5363 (print)

penyampaiannya meskipun itu outputnya sama (Ramadhani et al., 2020). Di masa pandemi, panutan yang pada awalnya keluar wajib berjabat tangan sebelum keluar rumah, sesuai protokol kesehatan yang ditetapkan pemerintah. Orang tua terus memberikan keteladanan dan pemahaman kepada keluarga untuk senantiasa bertindak secara cermat dan terukur dalam beragama dan berbangsa.

2. Pembiasaan di masa pandemi

Dalam ilmu psikologi, kebiasaan yang dilakukan seseorang sangat berhubungan dengan contoh teladan yang menjadi panutan dalam bertindak. Menurut Saepul ada syarat yang perlu diperhatikan dalam pelasanaan pembiasaan kepada anak, sebagai berikut: 1) mulailah dari hari ini, sebelum terlambat, karena sesuatu yang tidak dibiasakan sejak dini akan berdampak pada dewasanya, sebab anak akan memiliki kebiasaan lain yang berlawanan, pembiasaan memang butuh usaha keras, namun ini harus dilaksanakan dengan terus menerus, 2) metode pembiasaan ini merupakan sebuah pembiasaan yang memberikan kita konsekuensi, teguh pada pendirian jangan diberikan ruang untuk melanggar pembiasaan tersebut (Ramadhani et al., 2020). Di masa pandemi, semua kebiasaan berubah drastis tetapi tetap berakhlak dan saling menghormati dan memahami satu sama lain.

Membiasakan sesuatu yang baik kepada peserta didik membutuhkan kesabaran, baik dari guru maupun orang tua di rumah. Guru tidak bosan-bosan untuk selalu mengingatkan dan mengawali kegiatan pembelajaran dengan berdoa dan hal-hal baik lainnya. Orang tua senantiasa mendampingi mereka dalam belajar. Di sinilah kunci keberhasilan dalam menanamkan karakter atau akhlak yang baik kepada anak-anak. Ada sinergi Antara guru di sekolah dengan orang tua di rumah. Orang tua tidak boleh acuh kepada anak apalagi di saat pembelajaran dalam jaringan seperti saat ini.

\section{KESIMPULAN}

Strategi penanaman pendidikan akhlak kepada peserta didik melalui pembelajaran dalam jaringan dengan melakukan pendekatan kepada wali/orang tua peserta didik secara maksimal. Dalam kondisi pandemi seperti ini peran 
wali/orang tua peserta didik sangat signifikan, oleh karena itu pendekatan kepada mereka adalah sebuah keniscayaan. Melalaui peran aktif wali/orang tua tersebut dapat dilakukan; 1) Teladan di Masa Pandemi. Dalam hal ini penguatan yang diberikan orang tua adalah contoh terbaik dalam pandangan anak, karena segala tindak tanduknya, sopan santunnya, cara berpakaiannya dan tutur kata orang tua akan selalu diperhatikan dan akan ditiru oleh anak. 2) Pembiasaan di masa pandemi. Setidaknya ada syarat yang perlu diperhatikan dalam pelasanaan pembiasaan kepada anak, sebagai berikut: a) mulailah dari hari ini, sebelum terlambat, karena sesuatu yang tidak dibiasakan sejak dini akan berdampak pada dewasanya, sebab anak akan memiliki kebiasaan lain yang berlawanan, pembiasaan memang butuh usaha keras, namun ini harus dilaksanakan dengan terus menerus, b) metode pembiasaan ini merupakan sebuah pembiasaan yang memberikan kita konsekuensi, teguh pada pendirian jangan diberikan ruang untuk melanggar pembiasaan tersebut. Di masa pandemi, semua kebiasaan berubah drastis tetapi tetap berakhlak dan saling menghormati dan memahami satu sama lain.

\section{BIBLIOGRAFI}

[1] Anisah. (2017). Pengaruh Kematangan Emosi terhadap Coping pada Siswa Kelas VII di SMP N 4 Depok Sleman Yogyakarta. E-Journal Bimbingan Dan Konseling, 6(2).

[2] Anwar, S. (2021). Pendidikan Karakter: Kajian Perspektif Tafsir fi Zilalil Qur'an. Tulungagung: STAI Muhammadiyah Tulungagung.

[3] Aqil, D. I. (2018). Building Religious Characters Through a Biological Perspective. Al-Hayat: Journal of Islamic Education (AJIE), 2(2), 167-176.

[4] Budiman, A., \& Jailani. (2014). Pengembangan Instrumen Asesmen Higher Order Thinking Skill (HOTS) Pada Mata Pelajaran Matematika Smp Kelas Viii Semester 1, Jurnal Riset Pendidikan Matematika 1. Jurnal Riset Pendidikan Matematika, 2(1).

[5] Ikhwan, A. (2021). Metode Penelitian Dasar (Mengenal Model Penelitian dan Sistematikanya). Tulungagung: STAI Muhammadiyah Tulungagung.

[6] Ikhwan, A., Anwar, S., \& Mahmudah, N. (2021). Tahsin and Tahfidz Learning System at Integrated Islamic Elementary School (SDIT) Insan Madani During the Pandemic Covid-19. Al-Hayat: Journal of Islamic Education (AJIE), 5(1), $1-11$.

[7] Iwantoro. (2018). Kompetensi Guru Pendidikan Agama Islam dalam 
Pembelajaran di Era Digital. JIE (Journal of Islamic Education), 2(2), 139151.

[8] Lestari, N. (2015). Infrastruktur Internet di Indonesia dan Dunia.

[9] Maryano, A., \& Sholeh, S. (2021). Implanting Morals in The Implementation of the Distance Learning System. Edukasi: Jurnal Pendidikan Islam, 9(2), 219-228.

[10] Nasir, A. K., \& Prastowo, A. (2021). Implementasi Teknik Penilaian Blended Learning Pada Keterampilan Pembelajaran Fiqih Masa Pandemi Covid-19. JIE: Journal of Islamic Edication, 6(2), 173-184.

[11] Nasution, I dan Suharian, S. (2020). Peran Orang Tua Terhadap Anak Dalam program dari Rumah Di Masa Pandemi Covid-19.

[12] Rajab, W. (2009). Buku Ajar Epidemiologi untuk Mahasiswa Kebidanan. Jakarta: Penerbit Buku Kedokteran EGC.

[13] Ramadhani, Y. R., Masrul, M., Ramadhani, R., Rahim, R., Tamrin, A. F., Daulay, J. S., ... Simarmata, J. (2020). Metode dan Teknik Pembelajaran Inovatif. Medan: Yayasan Kita Menulis.

[14] Satariyah. (2020). Tantangan Guru Gagap Teknologi pada Pembelajaran Jarak Jauh.

[15] Suparnis. (2016). Pendidikan Islam Kontemporer: Problematika, Tantangan dan Perannya dalam Menghadapi Era Globalisasi. At-Ta'lim, 15(1), 225-248.

[16] Surahman, E., Santaria, R., \& Setiawan, E. I. (2020). Tantangan Pembelajaran Daring di Indonesia. Kelola: Journal of Islamic Education Management, 5(2), 89-98.

[17] Trucano, M. (2014). Education \& technology in an age of pandemics (revisited). EduTech.

[18] Uscher-Pines, L., Schwartz, H. L., Ahmed, F., Zheteyeva, Y., Meza, E., Baker, G., \& Uzicanin, A. (2018). School practices to promote social distancing in K12 schools: Review of influenza pandemi policies and practices. BMC Public Health, 18(1), 1-13.

[19] Wahyono, P., Husamah, H., \& Budi, A. S. (2020). Guru profesional di masa pandemi COVID-19: Review Implementasi, Tantangan, dan Solusi Pembelajaran Daring. Jurnal Pendidikan Profesi Guru, 1(1), 51-65.

[20] Yulianingsih, W., Suhanadji, Nugroho, R., \& Mustakim. (2021). Keterlibatan Orangtua dalam Pendampingan Belajar Anak selama Masa Pandemi Covid19. Jurnal Obsesi: Jurnal Pendidikan Anak Usia Dini, 5(2), 1138-1150. https://doi.org/https://doi.org/10.31004/obsesi.v5i2.740 